American Journal of Applied Sciences 5 (11): 1572-1579, 2008

ISSN 1546-9239

(C) 2008 Science Publications

\title{
Heat Transfer Investigation of Intake Port Engine Based on Steady-State and Transient Simulation
}

\author{
${ }^{1}$ Semin, ${ }^{2}$ Abdul Rahim Ismail, ${ }^{2}$ Rosli Abu Bakar and ${ }^{2}$ Ismail Ali \\ ${ }^{1}$ Institute of Technology Sepuluh Nopember, Surabaya 60111, Indonesia \\ ${ }^{2}$ Faculty of Mechanical Engineering, University Malaysia Pahang, 25000 Kuantan, Malaysia
}

\begin{abstract}
This research is presents the gas flow heat transfer investigation in the intake port of four stroke direct injection compression ignition engine using GT-Suite software for steady-state and transient simulation. To investigate and simulate the intake port gas flow heat transfer profile of compression ignition engine is using GT-Power engine model were developed in this research. GTPower is sub-system menu from GT-Suite. The engine model is developed from the real compression ignition engine data and input to software library. In this research, the simulation of engine model is running in variations engine speeds. The simulation output data is collected from the GT-Post results plots and casesRLT in post processing. The simulation results of the intake port engine model are shown the characters in intake port heat transfer profile of engine in variations engine speeds. The detail performance intake port gas flow heat transfer is shown that in $3500 \mathrm{rpm}$ engine speed is the best
\end{abstract}

Key words: Compression ignition engine, computational model, heat transfer, intake port, simulation

\section{INTRODUCTION}

Engine modeling is a very large subject, in part because of the range of engine configurations possible and the variety of alternative analytical techniques or sub-models, which can be applied in overall engine models ${ }^{[8]}$. Engine modeling is a fruitful research area and as a result many universities have produced their own engine thermodynamics models, of varying degrees of complexity, scope and ease to use. There are also now available a number of fairly comprehensive models which have a wider, more general purpose use with refined inputs and outputs to facilities their use by engineers other than their developers, most of these models had their origins in university-developed models. They include WAVE from USA, PROMO from Germany, TRANSEG/ICENG/MERLIN from UK, among others. A new code covering completes engine systems have emerged recently, GT-Suite $e^{[8]}$.

In this research the steady-state and transient simulation using GT-Suite of gas flow heat transfer in intake port of four stroke direct injection compression ignition engine is presented. The aim is to give an insight into the engine intake port gas flow thermodynamics performance using GT-Suite simulation model, how the engine model developed and how the components interact. This research is focuses on intake port gas flow heat transfer characteristics of engine in variations engine speeds.
Direct injection compression ignition engines is internal combustion engines, where fuel is injected by the fuel injection system into the engine cylinder toward the end of the compression stroke, just before the desired start of combustion. The liquid fuel, usually injected at high velocity as one or more jets through small orifices or nozzles in injector tip, atomizes into small drops and penetrates into the combustion chamber. The fuel vaporizes and mixes with high temperature and high pressure cylinder air. The air is supplied from intake port of engine. Since the air temperature and pressure are above the fuel's ignition point, spontaneous ignition of portions of the alreadymixed fuel and after air a delay period of a few crank angle degrees. The cylinder pressure increases as combustion of the fuel-air mixture occurs ${ }^{[1,8,9,16,17]}$. The major problem in compression ignition engine combustion chamber design is achieving sufficiently rapid mixing between the injected fuel and the air from intake port in the cylinder to complete combustion in the appropriate crank angle interval close to topcenter $^{[2,4,7,8,11,12,14,15,18,22]}$. To determine gas flow conditions right through the engine is the essence of modeling at small intervals time. Appropriate summation of these gas conditions over an engine cycle then leads to an estimate engine performance. Gas flow condition through the engine is basically meant pressures, temperatures, gas composition and mass or energy flows. The core of any model is the energy Eq.

Corresponding Author: Semin, Institute of Technology Sepuluh Nopember, Campus ITS, Sukolilo, Surabaya, Indonesia 1572 
for each control volume in the engine ${ }^{[8]}$. The first essential the engine performance model is the energy for a control volume, which is derived from First Law Thermodynamics and the Perfect Gas Law. The first law states that the rate of change of internal energy of the volume from connected gas flows, less any nett heat transfer out through the volume walls and less any work done by the control volume gas against its surroundings is shown in Eq. (1).

$$
\frac{\mathrm{d}(\mathrm{uM})}{\mathrm{dt}}=\sum_{\mathrm{l}} \mathrm{h}_{\mathrm{i}} \dot{\mathrm{m}}_{\mathrm{i}}-\frac{\mathrm{dQ}}{\mathrm{dt}}-\mathrm{P}\left(\frac{\mathrm{dV}}{\mathrm{dt}}\right)
$$

where, $\mathrm{u}$ is the specific internal energy per unit mass of gas in the control volume and there are 1 pipes connecting to the control volume, the flow in the ith pipe having specific enthalpy $h_{i}$ and mass flow rate $m_{i}$ (negative for outflow). Net heat transfer out of the control volume is $\mathrm{dQ} / \mathrm{dt}, \mathrm{M}$ is the mass of gas in the control volume at pressure $\mathrm{P}$ and this gas carrier out nett work on its surroundings of $\mathrm{PdV} / \mathrm{dt}$, where $\mathrm{dV} / \mathrm{dt}$ is the control volume's current rate of change of volume (zero for manifold control volume and not for cylinder control volume).

To determine flow through a pipe and constriction is needed the orifice Eq.. The stagnation or total temperature $T_{t}$ at any point in a flow is given by Eq. (2).

$$
c_{p} T_{t}=c_{p} T+\frac{v^{2}}{2}
$$

where, $T_{t}$ is the temperature that the gas flowing at velocity $\mathrm{v}$ with static temperature $\mathrm{T}$ would reach if it were brought to rest adiabtically, the Eq. is simply an energy balance, $c_{\mathrm{p}} \mathrm{T}$ being a measure of the static energy, $v^{2} / 2$ the kinetic energy and $c_{p} T_{t}$ the total energy (enthalpy). And to determine the mach number $\mathrm{Ma}$ is using Eq. (3), where c is velocity of sound, $\gamma$ is equal with $\mathrm{cp} / \mathrm{cv}$ and $\mathrm{cp}-\mathrm{cv}=\mathrm{R}$.

$$
M_{a}=\frac{v}{c}=\frac{v}{\sqrt{(\gamma R T)}}
$$

The total to static temperature relationship is obtained using Eq. (4) and (5). Then the total to static pressure Eq. is shown in Eq. (6).

$$
\frac{\mathrm{T}_{\mathrm{t}}}{\mathrm{T}}=1+\frac{\mathrm{v}^{2}}{2 \mathrm{c}_{\mathrm{p}}}=1+\frac{\gamma \mathrm{RTM}_{\mathrm{a}}{ }^{2}}{2 \mathrm{c}_{\mathrm{p}}}
$$

$$
\begin{aligned}
& \frac{\mathrm{T}_{\mathrm{t}}}{\mathrm{T}}=1+(\gamma-1) \frac{\mathrm{M}_{\mathrm{a}}^{2}}{2} \\
& \frac{\mathrm{P}_{\mathrm{t}}}{\mathrm{P}}=\left(\frac{\mathrm{T}_{\mathrm{t}}}{\mathrm{T}}\right)^{\frac{\gamma}{\gamma-1}}=\left[1+\left(\frac{\gamma-1}{2}\right) \mathrm{M}_{\mathrm{a}}{ }^{2}\right]^{\frac{\gamma}{\gamma-1}}
\end{aligned}
$$

However, the mass flow Eq. gives mass flow $\dot{m}$ at any point in a flow where flow velocity is $\mathrm{v}$, flow area is A and flow density is $\rho$.

$$
\dot{\mathrm{m}}=\rho \mathrm{Av}
$$

For convection and conduction heat transfer, the heat flow rate through a material layer of the intake port engine is given in Eq. (8).

$$
\dot{\mathrm{Q}}=\mathrm{hA}\left(\mathrm{T}_{\mathrm{h}}-\mathrm{T}_{\mathrm{c}}\right)
$$

where, $h$ is the layer heat transfer coefficient per unit area, $A$ is the heat transfer surface area and $T_{h}, T_{c}$ is the hot and cold side surface temperature.

\section{MATERIALS AND METHODS}

The four stroke direct injection compression ignition engine model has been developed using GTPOWER software. The engine model is developed based on real engine selected data. According to Bakar $^{[3,5,6]}$, Ismail ${ }^{[13]}$ and Semin ${ }^{[18-21]}$, the specification of the intake port of engine is shown in Table 1 and specification of selected engine is shown in Table 2.

Table 1: Intake port specification

\begin{tabular}{ll}
\hline Intake port parameter & Value \\
\hline Diameter inlet end $(\mathrm{mm})$ & 40.69 \\
Diameter outlet end $(\mathrm{mm})$ & 32.78 \\
Length $(\mathrm{mm})$ & 55.2 \\
Discreatization length $(\mathrm{mm})$ & 34.4 \\
Wall temperature $\left({ }^{\circ} \mathrm{C}\right)$ & 176.85 \\
\hline
\end{tabular}

\begin{tabular}{ll} 
Table 2: Engine specification & \\
\hline Engine Parameters & Value \\
\hline Bore $(\mathrm{mm})$ & 86.0 \\
Stroke $(\mathrm{mm})$ & 70.0 \\
Displacement $(\mathrm{cc})$ & 407.0 \\
Number of cylinder & 1 \\
Connecting rod length (mm) & 118.1 \\
Exhaust valve open (EVO) $\left({ }^{\circ} \mathrm{CA}\right)$ & 147 \\
Exhaust valve close $(\mathrm{EVC})\left({ }^{\circ} \mathrm{CA}\right)$ & 282 \\
Intake valve open $(\mathrm{IVO})\left({ }^{\circ} \mathrm{CA}\right)$ & 395 \\
Intake valve close $(\mathrm{IVC})\left({ }^{\circ} \mathrm{CA}\right)$ & 530 \\
Injection Start $\left({ }^{\circ} \mathrm{CA}\right)$ & -22.0 \\
Number of nozzle injector & 1 \\
Number of nozzle injector holes & 4 \\
Diameter of nozzle injector holes $(\mathrm{mm})$ & 0.1 \\
\hline
\end{tabular}


In the GT-POWER engine model development, a typical intake port is modeled using Import, engine is modeled using EngCylinder and EngineCrankTrain component objects, Valve*Conn and EngCylConn connection objects. Inport is used to define the basic geometry and characteristics of intake port, EngCylinder and EngineCranktrain are used to define the basic geometry and characteristics of engine ${ }^{[5,6,10,18,20]}$. These objects further refer to several reference objects for more detailed modeling information on such attributes as gas flow, combustion and heat transfer. Inport must be connected to the engine cylinder with Valve*Conn, Cylinder must be connected to the engine with EngCylConn part made from the predefined object which available in the template library. While Pipe, EngCylConn parts have no user defined attributes, the global cylinder number for cylinder is assigned by the port number where the EngCylConn connection is attached to the engine. Cylinder are connected to intake and exhaust ports with Valve*Conn connections. Many Valve*Conn connection templates are available to define different types of valve, port and their characteristics. To create the GT-POWER model, select window and then Tile with Template Library from the menu. This will place the GT-POWER template library on the left hand side of the screen. The template library contains all of the available templates that can be used in GT-POWER. Some of these templates those that will be needed in the project need to be copied into the project before they can be used to create objects and parts. For the purpose of this model, click on the icons listed and drag them from the template library into the project library. Some of these are templates and some are objects that have already been defined and included in the GT-POWER template library. Then, the engine components size data input to the GT-POWER library of the all engine components data. All of the parameters in the model will be listed automatically in the case setup and each one must be defined for first case of the simulation. According to Bakar ${ }^{[5,6]}$ and Semin ${ }^{[18]}$, the engine model developed is shown in Fig. 1.

In the Fig. 1, i-1 is intake environment, $\mathrm{i}-3$ is intrunnerairfilter, i-5 is air filter, i- 7 is intrunner, $i-9$ is import, i-10 is intvalve, en-11 is injector, en-12 is engine cylinder, en-14 is engine cranktrain, e-15 is exhvalve, e-16 is exhport, e-18 is exhrunner, e-20 is muffler, e-22 is exhrunnerexit and e-24 is exhaust environment. Components i-1 until i-10 is for intake system, en-11 until en-14 is for injection and engine and e-15 until e-24 is for exhaust system.

The solver of GT-POWER determines the performance of an engine simulation based on engine

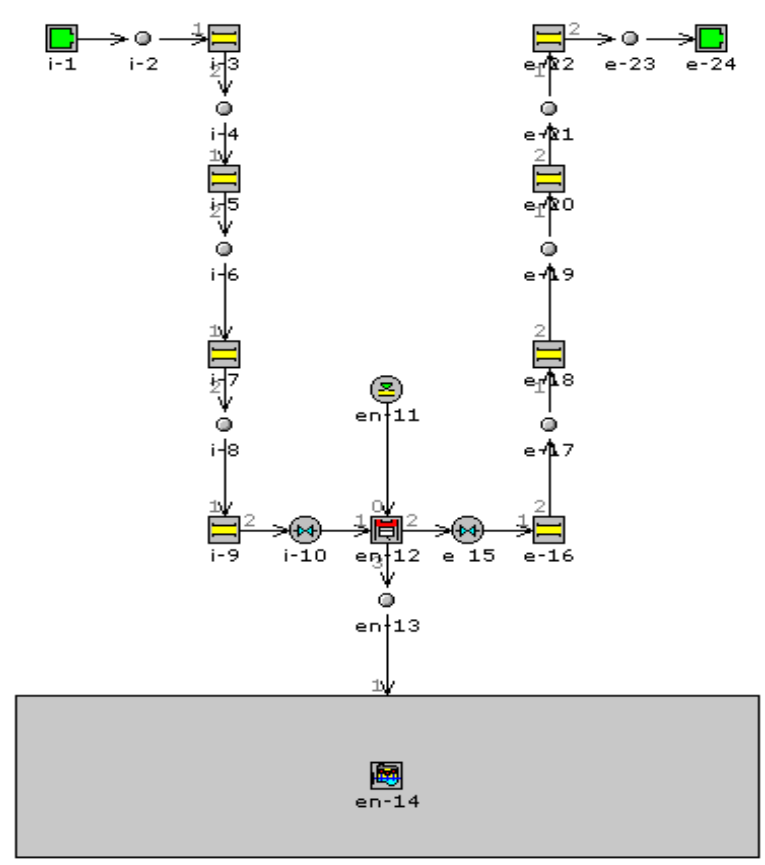

Fig. 1: Single-cylinder direct injection compression ignition engine model using GT-POWER

speed mode in the EngineCrankTrain object. Speed mode is the most commonly used mode of engine simulation, especially for steady states cases ${ }^{[10]}$. In the research imposes the engine speed as either constant or by a dependency reference object. This method typically provides steady-state results very quickly because the speed of the engine is imposed from the start of the simulation, thus eliminating the relatively long period of time that a loaded engine requires for the crankshaft speed to reach steady-state.

\section{RESULTS AND DISCUSSION}

Gas flow heat transfer steady-state and transient simulations of the intake port of four stroke direct injection compression ignition engine model is running in 8 cases engine speed. Case 1 is engine model running at $500 \mathrm{rpm}$, case 2 is engine model running at 1000 $\mathrm{rpm}$, case 3 is engine model running at $1500 \mathrm{rpm}$, case 4 is engine model running at $2000 \mathrm{rpm}$, case 5 is engine model running at $2500 \mathrm{rpm}$, case 6 is engine model running at $3000 \mathrm{rpm}$, case 7 is engine model running at $3500 \mathrm{rpm}$ and case 8 is engine model running at 4000 $\mathrm{rpm}$. In this research, the result of the model is viewed from GT-Post plots and GT-Post casesRLT.

The heat transfer coefficient in intake port simulation results are shown in Fig. 2-9. The result in Fig. 2 shows the heat transfer coefficient in intake port 
Am. J. Applied Sci., 5 (11): 1572-1579, 2008

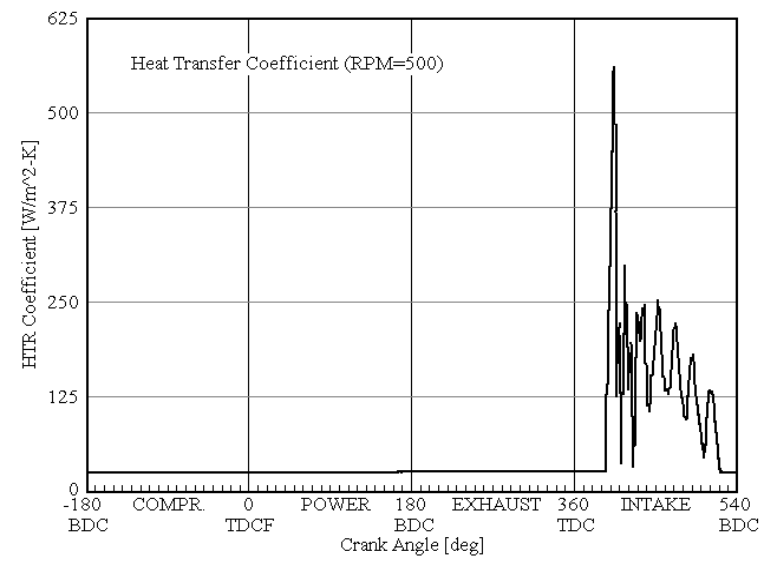

Fig. 2: Heat transfer coefficient in intake port of engine at $500 \mathrm{rpm}$

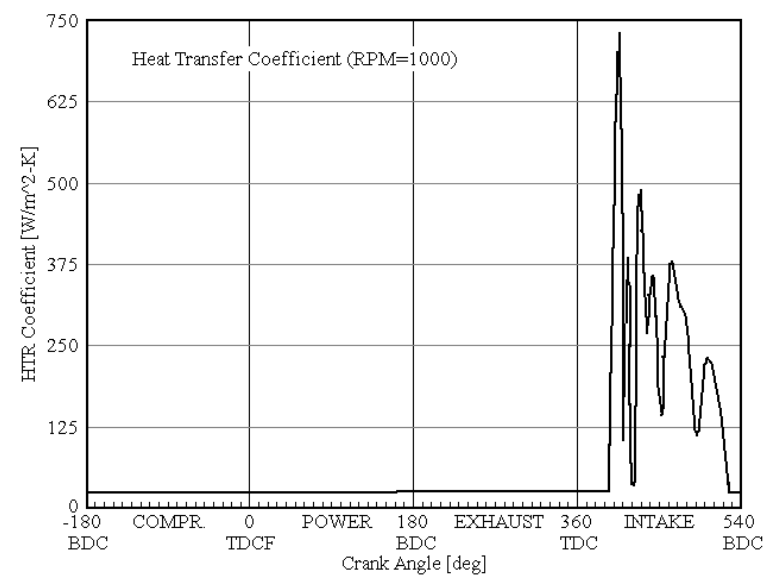

Fig. 3: Heat transfer coefficient in intake port of engine at $1000 \mathrm{rpm}$

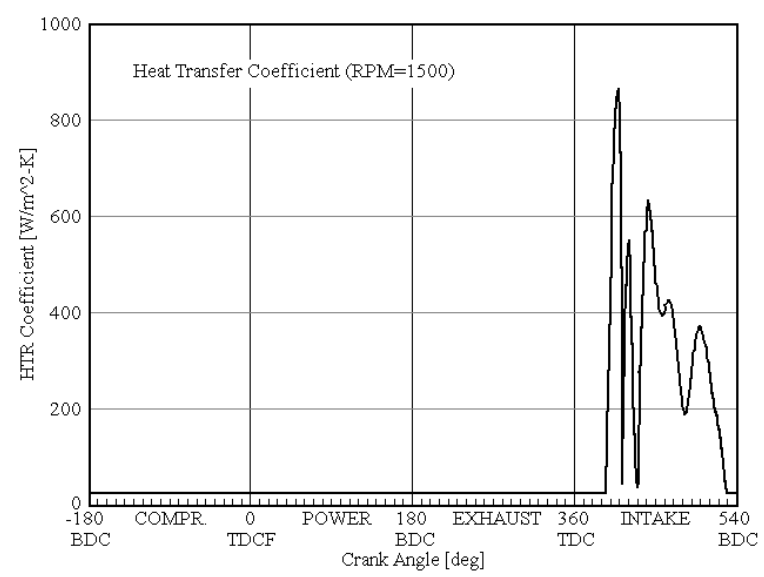

Fig. 4: Heat transfer coefficient in intake port of engine at $1500 \mathrm{rpm}$

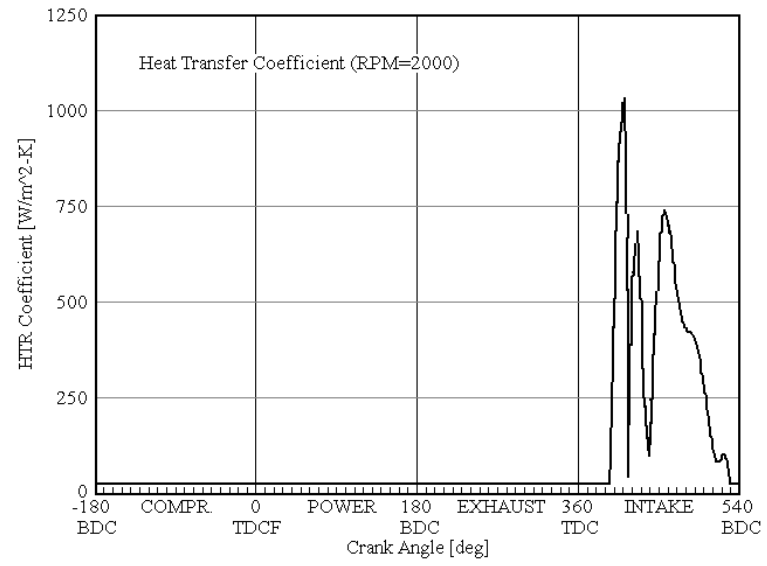

Fig. 5: Heat transfer coefficient in intake port of engine at $2000 \mathrm{rpm}$

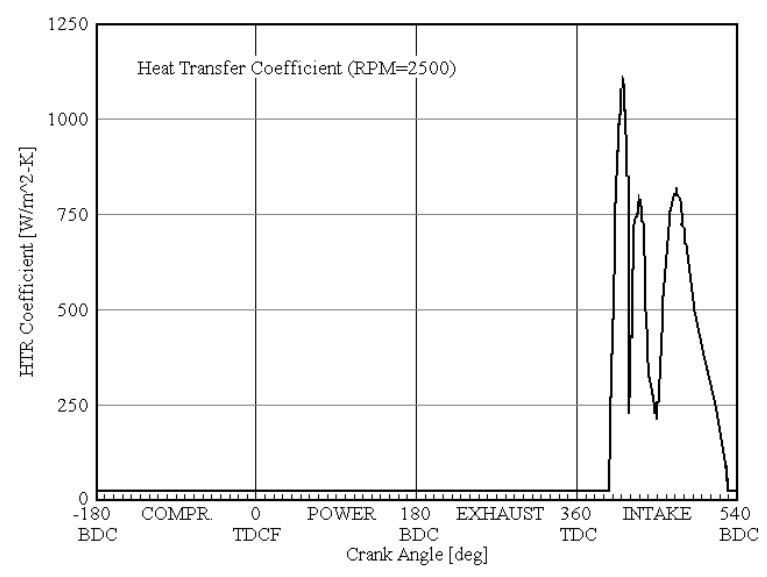

Fig. 6: Heat transfer coefficient in intake port of engine at $2500 \mathrm{rpm}$

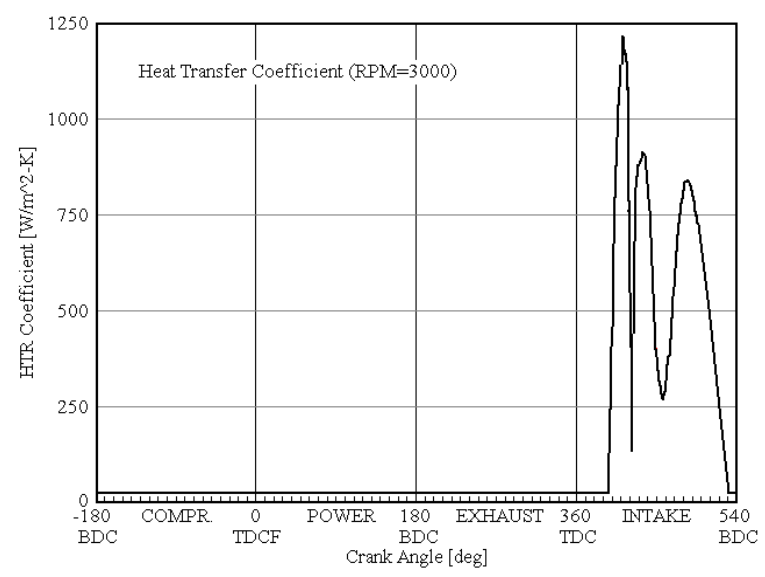

Fig. 7: Heat transfer coefficient in intake port of engine at $3000 \mathrm{rpm}$ 


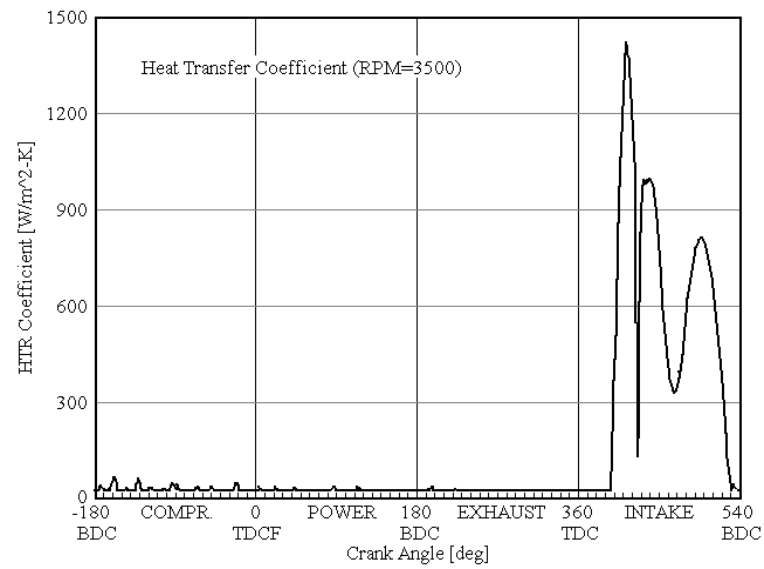

Fig. 8: Heat transfer coefficient in intake port of engine at $3500 \mathrm{rpm}$

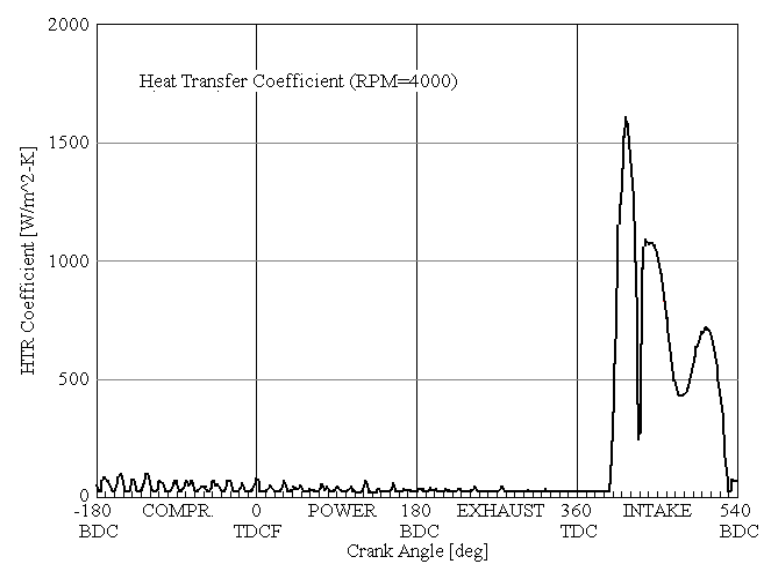

Fig. 9: Heat transfer coefficient in intake port of engine at $4000 \mathrm{rpm}$

of engine at $500 \mathrm{rpm}$ engine speeds, Fig. 3 shows the heat transfer coefficient in intake port of engine at 1000 rpm engine speeds, Fig. 4 shows the heat transfer coefficient in intake port of engine at $1500 \mathrm{rpm}$ engine speeds, Fig. 5 shows the heat transfer coefficient in intake port of engine at $2000 \mathrm{rpm}$ engine speeds, , Fig. 6 shows the heat transfer coefficient in intake port of engine at $2500 \mathrm{rpm}$ engine speeds, Fig. 7 shows the heat transfer coefficient in intake port of engine at 3000 rpm engine speeds, Fig. 8 shows the heat transfer coefficient in intake port of engine at $3500 \mathrm{rpm}$ engine speeds and Fig. 9 shows the heat transfer coefficient in intake port of engine versus crank angle at $4000 \mathrm{rpm}$ engine speeds.

The fluid to wall heat transfer rate in intake port of engine simulation results are shown in Fig. 10-17. The result in Fig. 10 shows the fluid to wall heat transfer

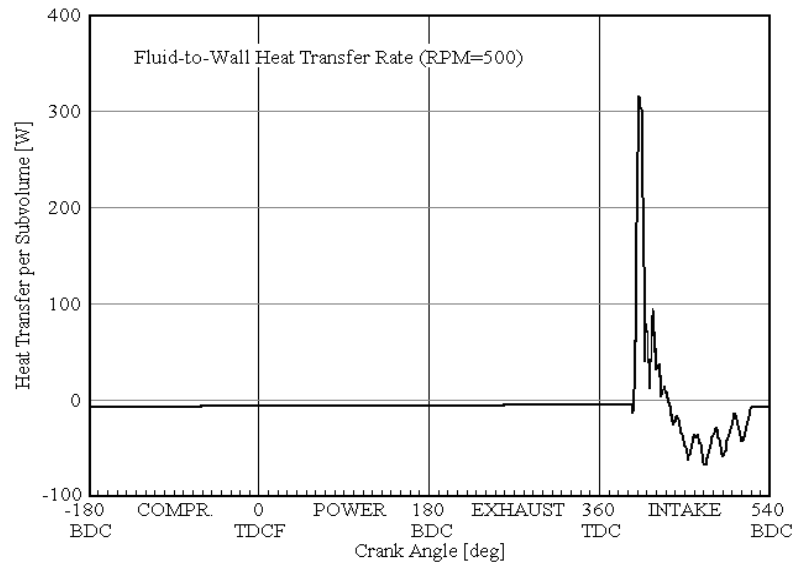

Fig. 10: Fluid to wall heat transfer rate in intake port of engine at $500 \mathrm{rpm}$

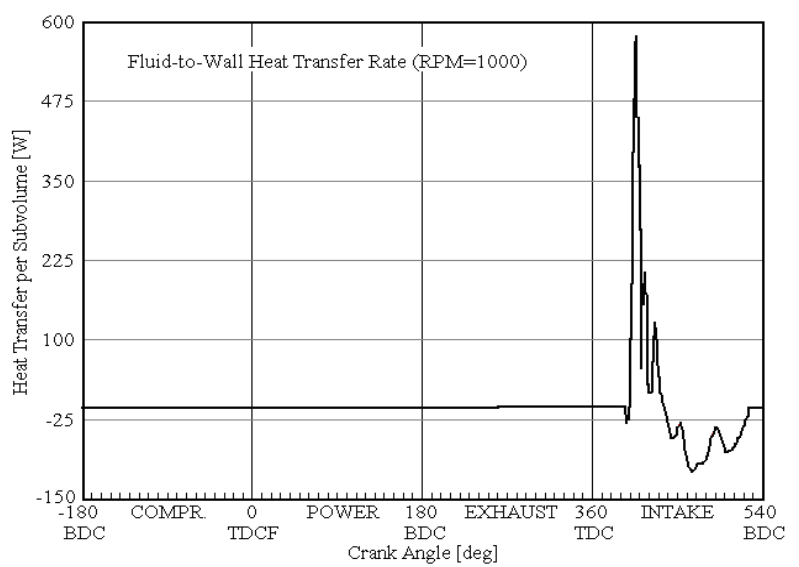

Fig. 11: Fluid to wall heat transfer rate in intake port of engine at $1000 \mathrm{rpm}$

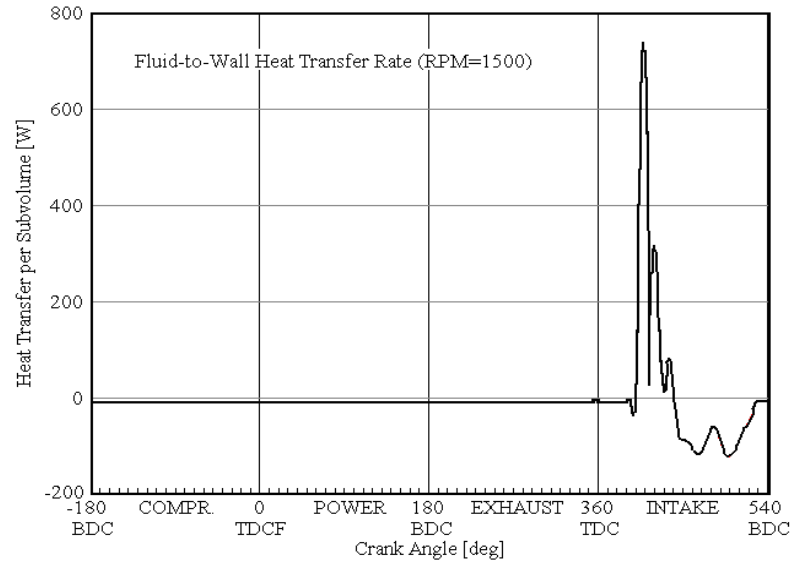

Fig. 12: Fluid to wall heat transfer rate in intake port of engine at $1500 \mathrm{rpm}$ 


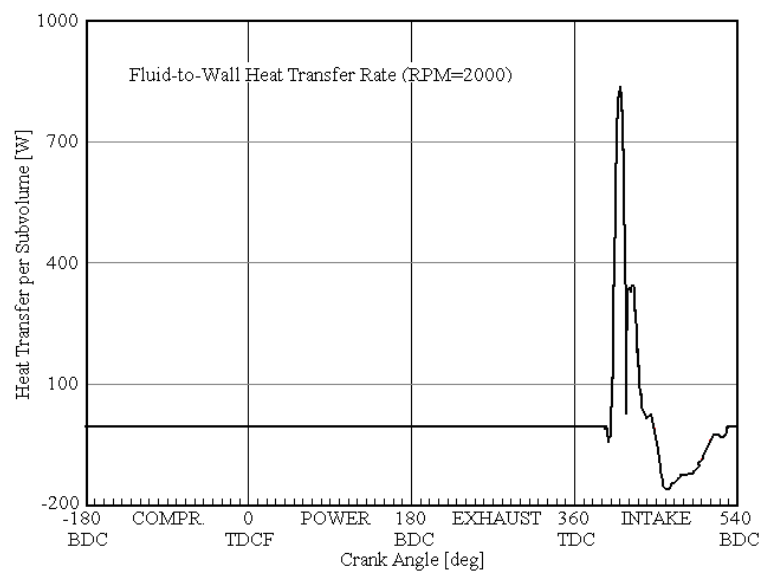

Fig. 13: Fluid to wall heat transfer rate in intake port of engine at $2000 \mathrm{rpm}$

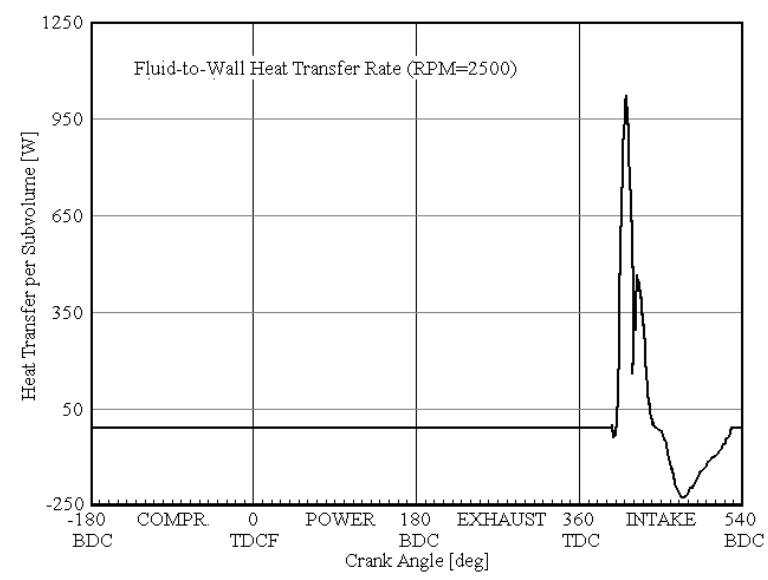

Fig. 14: Fluid to wall heat transfer rate in intake port of engine at $2500 \mathrm{rpm}$

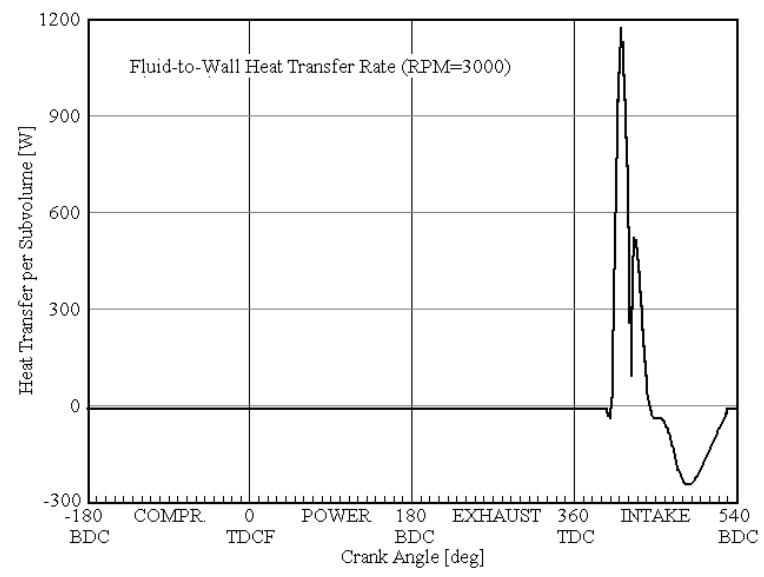

Fig. 15: Fluid to wall heat transfer rate in intake port of engine at $3000 \mathrm{rpm}$

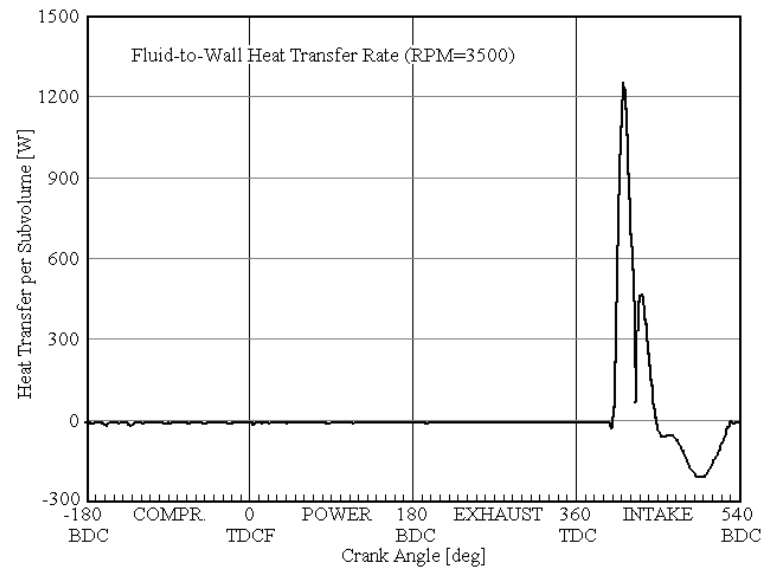

Fig. 16: Fluid to wall heat transfer rate in intake port of engine at $3500 \mathrm{rpm}$

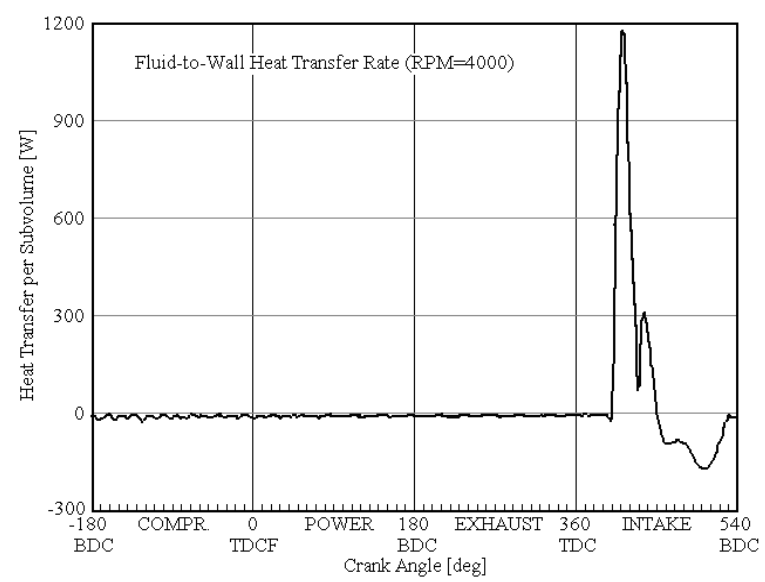

Fig. 17: Fluid to wall heat transfer rate in intake port of engine at $4000 \mathrm{rpm}$

rate versus crank angle in intake port of engine at 500 rpm engine speed, Fig. 11 shows the fluid to wall heat transfer rate versus crank angle in intake port of engine at $1000 \mathrm{rpm}$ engine speed, Fig. 12 shows the fluid to wall heat transfer rate versus crank angle in intake port of engine at $1500 \mathrm{rpm}$ engine speed, Fig. 13 shows the fluid to wall heat transfer rate versus crank angle in intake port of engine at $2000 \mathrm{rpm}$ engine speed, Fig. 14 shows the fluid to wall heat transfer rate versus crank angle in intake port of engine at $2500 \mathrm{rpm}$ engine speed, Fig. 15 shows the heat transfer coefficient in intake port of engine versus crank angle profile at 3000 rpm engine speeds, Fig. 16 shows the fluid to wall heat transfer rate versus crank angle in intake port of engine at $3500 \mathrm{rpm}$ engine speed and Fig. 17 shows the fluid to wall heat transfer rate versus crank angle in intake port of engine at $4000 \mathrm{rpm}$ engine speed. 
The heat transfer coefficient versus crank angle in intake port of engine in variations engine speeds simulations results shown that in direct injection four stroke of compression ignition engine, the nominal point in the compression stroke, power stroke and exhaust stroke is near zero point because in this stroke the intake valve is closed so the heat from combustion process in engine cylinder not interaction and gas is unflow to intake port. It very different if the intake valve is opened, the heat from un-excellent gas flow to exhaust valve is still in engine cylinder and quickly flow out to intake valve and intake port if the intake valve is opened. The Fig. 2 - Fig 9 shows that in early intake valve opened the heat transfer coefficient is extremely high in quickly time, then go to un-stability heat transfer coefficient to the down line because the valve lift is go to lower and lower then to closed and the end the heat transfer coefficient is go to compression stroke line because the intake valve lift is zero or intake valve is closed. Its mean that in intake valve is closed in the intake port is no heat transfer coefficient outlet and heat transfer coefficient inlet, so the heat transfer coefficient is stabile or same with compression stroke, power stroke and exhaust stroke. Heat transfer coefficient in intake port is increase if the engine speed is increasing, so the lowest is in lowest engine speed and the highest is in highest engine speed. In this simulation the lowest heat transfer coefficient is in $\mathbf{5 0 0}$ rpm engine speed and the highest heat transfer coefficient is in $4000 \mathrm{rpm}$ engine speed position. In the lower engine speed the exhaust gas flow is more excellent than the higher engine speed so in intake port in lower speed engine the heat gas from engine cylinder is lower than in the higher engine speed position.

The fluid to wall heat transfer rate versus crank angle degree in intake port of engine in variations engine speeds simulations results shown in Fig. 10 Fig. 17. From these figures shows that in direct injection four stroke of compression ignition engine, the nominal point in the compression stroke, power stroke and exhaust stroke is in zero point because in this stroke the intake valve is closed so the heat from combustion process in engine cylinder not interaction with intake port wall and heat gas from fluid combustion is not flow to intake port wall. It very different if the intake valve is opened, the heat from un-excellent gas flow to exhaust valve is still in engine cylinder and quickly flow out to intake valve and intake port wall if the intake valve is opened. The Fig. 10-17 shows that in early intake stroke where intake valve is opened the fluid to wall heat transfer rate is extremely highest in quickly time and crank angle degree, then go to down and un-stability fluid to wall heat transfer rate until

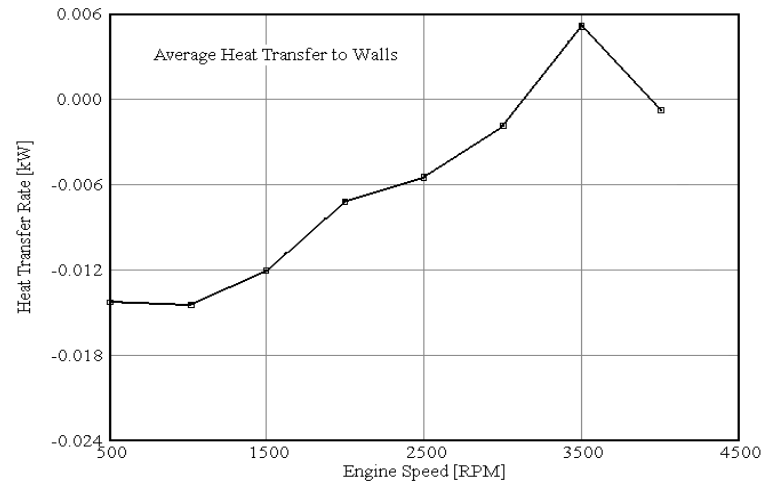

Fig. 18: Averaged heat transfer to walls in intake port of engine in variations engine speed

under zero pint and go to normal or zero point fluid to wall heat transfer rate line because the valve lift is go to lower and lower then to closed and the end the fluid to wall heat transfer rate is end in intake stroke and go to compression stroke line because the intake valve lift is zero or intake valve is closed. Its mean that in the end of intake stroke and intake valve is closed, in the intake port is no fluid to wall heat transfer rate outlet and fluid to wall heat transfer rate inlet, so the fluid to wall heat transfer rate is stabile or same with compression stroke, power stroke and exhaust stroke. The trend result of the nominal fluid to wall heat transfer rate is shown that increasing engine speed can be increase the fluid to wall heat transfer rate. The lowest is in $500 \mathrm{rpm}$ and the highest is in $3500 \mathrm{rpm}$.

The averaged heat transfer to walls in intake port in variations engine speed is shown in Fig. 18. The result trend shows that the averaged heat transfer to walls in intake port of engine in variations engine speed that the lowest is in $1000 \mathrm{rpm}$ engine speed and the highest is in $3500 \mathrm{rpm}$ engine speed. Because in the $3500 \mathrm{rpm}$ engine speed, the mass averaged total temperature inlet, outlet and fluid to wall heat transfer rate is highest than the other speed. Its mean that in $3500 \mathrm{rpm}$ engine speed the combustion is most excellently.

\section{CONCLUSSION}

Heat transfer coefficient, fluid to wall heat transfer rate and mass averaged total temperature inlet versus crank angle degree is stabile in the compression stroke, power stroke and exhaust stroke of the engine operating cycle, its shown that in these stroke the heat transfer phenomena is near zero. The heat transfer is extremely highest in intake stroke, because in the stroke the interaction of gas in engine cylinder and intake port is opened. Mass averaged total temperature outlet and 
averaged heat transfer to walls in intake port versus engine speed is increase in increasing of engine speed until $3500 \mathrm{rpm}$ engine speed. It means that the best combustion of engine is in $3500 \mathrm{rpm}$ engine speed.

\section{REFERENCES}

1. Atkinson, C.M., G.J. Thompson, M.L. Traver and N.N. Clark, 1999. In-cylinder combustion pressure characteristics of Fischer- Tropsch and conventional diesel fuels in a heavy-duty CI engine, SAE Paper 1999-01-1472.

2. Bakar, R.A., Semin, 2006. The internal combustion engine diversification technology for the future: A Review, Proceeding of International Seminar IMarEST-ITS, Surabaya, Indonesia.

3. Bakar, Rosli A., Semin., 2006. Investigation of fuel nozzle performance on direct injection diesel engines using computational simulation, MARINEJ., Vol. 3 (2).

4. Bakar, R.A., Semin and A.R. Ismail, 2007. The internal combustion engine diversification technology and fuel research for the future: A Review, Proc.e AEESEAP Symposium, Malaysia.

5. Bakar, R.A., Semin and A.R. Ismail, 2007. Effect of engine performance for four-stroke diesel engine using simulation, proceeding the 5th NAE International Conference, Indonesia.

6. Bakar, R.A., Semin and A.R. Ismail, 2007. Development of intake and exhaust stroke flow simulation in an engine cylinder using CFD Model, Proc. of NaCSEC Conference, Malaysia.

7. Blair, Gordon. P., 1999. Design and simulation of four stroke engines, SAE Inc. USA.

8. Challen, Bernard., R. Baranescu, 2003. Diesel engine reference book, Elsevier, Oxford, U.K.

9. Eriksson, Lars. andersson, Ingemar., 2002. An analytic model for cylinder pressure in a fourstroke SI engine, SAE Paper 2002-01-0371.

10. Gamma Technologies, 2003. GT-POWER user manual, Gamma Technologies, Inc.
11. Ganesan, V., 1999. Internal Combustion Engines 2nd Edn., Tata McGraw-Hill, New Delhi.

12. Heywood, J.B., 1998. Internal Combustion Engine Fundamentals. McGraw-Hill, Singapore.

13. Ismail, Abdul.R., Semin., Bakar, R.A., 2007. Valve Flow Discharge Coefficient Investigation for Intake and Exhaust Port of Four Stroke Diesel Engines, J. Eng. App. Sci. 2 (12): 1807-1811.

14. Klein, M., Eriksson and Nilsson, 2002. Compression estimation from simulated and measured cylinder pressure, SAE Paper 200201-0843.

15. Kowalewicz, A., 1984. Combustion System of High-Speed Piston I.C. Engines, Warszawa.

16. Piedrahita, C.A.R. and H.F.Q. Riaza, 2003. Prediction of in-cylinder pressure, temperature and loads related to the crank-slider mechanism of I.C. Engines, SAE Paper 2003-01-0728.

17. Sanders, S.T., T. Kim and J.B. Ghandhi, 2003. Gas temperature measurements during ignition in an HCCI engine, SAE Paper 2003-01-0744.

18. Semin., A.R. Ismail and R.A. Bakar, 2007. In an engine valve lift visualization and simulation performance using CFD, Proc. of CADME Conference, Malaysia.

19. Semin, R.A. Bakar, A.R. Ismail, 2007. Air flow analysis of four stroke direct injection diesel engines based on air pressure input and L/D Ratio, Res. J. App. Sci. 2 (11): 1135-1142.

20. Semin and R.A. Bakar, 2007. Nozzle holes effect on unburned fuel in injected and in-cylinder fuel of four stroke direct injection diesel engine, Res. J. App. Sci. 2 (11): 1165-1169.

21. Semin, R.A. Bakar and A.R. Ismail, 2007. Engine power calculation using air flow through engine from flowbench test flow of four stroke di diesel engines, J. Eng. App. Sci. 2 (12): 1812-1817.

22. Stone, Richard, 1997. Introduction to Internal Combustion Engines-2nd Edn., SAE Inc, USA. 